Pakistan Journal of Social Sciences 7 (5): 365-370, 2010

ISSN: $1683-8831$

(C) Medwell Journals, 2010

\title{
Perceived Factors Responsible for Dropout in Primary Schools in Delta Central Senatorial District, Nigeria
}

\author{
N. Osakwe Regina and O. Osagie Stella \\ Department of Educational Administration and Policy Studies, \\ Faculty of Education, Delta State University, Abraka, Nigeria
}

\begin{abstract}
The study was designed to investigate the perceived factors responsible for dropout in primary school in Delta Central Senatorial District, Nigeria. The population of the study comprised all the public primary schools. Four hypotheses were formulated and tested using the one-way Analysis Of Variance (ANOVA) at 0.05 level of significance. The sample of 500 respondents was selected using the simple random sampling technique. The instrument used was the questionnaire and its face and content validity was established. The reliability coefficient value of 0.87 was established using the split half method to test the instrument's internal consistency making it reliable for the study. The study revealed that there was no significant difference among the perception of school heads, teachers and parents on parents socio-economic status, early marriage, gender and parents perception on the value of education. Based on the findings and conclusion, it was recommended that school materials such as textbook and writing materials should be provided. Parents should give equal educational opportunities to both boys and girls.
\end{abstract}

$\underline{\text { Key words: Dropout, gender, early marriage, education, socio-economic status, parents }}$

\section{INTRODUCTION}

Primary education forms the basis of entire system of education. Its importance lies in the fact that it serves as the foundation stone on which the subsequent edifice of the education system is raised. The immense contribution it makes to the overall development of the country is indicated by the research studies undertaken in both developed and developing countries including Nigeria, in order to achieve the universalization of primary education. Today, education has become the contemporary creed and about the surest way to attain self-reliance and economic growth and development. This was why the federal Government of Nigeria established the Universal Basic Education (UBE) Programme in 1999 to primarily:

- Provide a compulsory, free and universal basic education, for every Nigerian child of school age

- Reduce drastically the incidence of dropout from formal school system through improved relevance, quality and efficiency

- Ensuring the acquisition of the appropriate level of literacy, communicative and life skills as well as the ethical, moral and civil values needed for laying, a solid foundation for life long learning etc.

But what we discover is dropout among primary school pupils especially in Delta Central Senatorial
District. The society at large helps to contribute to the dropout problems in the sense that society cherishes wealth and honour wealthy men. The poor man has no place at all. The importance tge society attaches to wealth lure the young boys and girls to pursue wealth rather than education which is of life lasting value and legacy.

In this district, thorough observation and careful study reveals that children of school age go in search of quick money by performing odd and menial jobs such as bus conductors, sellers along the road and in the market places, wheelbarrow pushers, mechanic apprentice etc. The notion of these boys is that, to stay and complete primary six especially those who started late is a waste of time, money and energy. What they do is quietly withdraw from school and pursue wealth no matter how hard and rough the road is to acquiring it. Second observation is as a result of instability of the school system due to frequent strike action and regular changes in government, thereby resulting in inconsistent policy on educational matters such changes in school curriculum textbooks and policies in school administration. This has lead many pupils mostly females into teenage pregnancy and early marriage while the boys go into joining of gangs that are deviant in nature and eventually stay away from school. The phenomenon of dropout in primary schools has dire consequences on educational system. It leads to wastage on one hand and under utilization of facilities on the other for instance if a school does not have sufficient

Corresponding Author: N. Osakwe Regina, Department of Educational Administration and Policy Studies, Faculty of Education, Delta State University, Abraka, Nigeria 
enrolment, we can say there is a wastage of school capacity hence Fafunwa (1983) says that Dropout is a major problem that continue to be-devil the educational system since the beginning of Western education in Nigeria in the mid 19th century to the present. It is also worth noting that the phenomena of dropout is not only common to Nigeria's Delta Central Senatorial District per se but also high in other parts of the countries of the world e.g., a survey carried out in the whole European community showed $20 \%$ of the European governing people age 18-20 are kept out of the society of knowledge. In Italy, a survey carried out in Primary and Junior Secondary Schools, showed that in Primary Schools, dropout are of a physiological type and it has become quite relevant in both Primary and Junior Schools. In America, millions of young people are dropouts without a school certificate or diploma (Schwartz, 1995).

In Nigeria, the case of Delta Central Senatorial District is not different from what obtains in the outside world. In order for the individual to be self-reliant, he has to be educated. Education is considered to be important to mankind hence the Nigeria Government got involved in the management of education right from the time of Arthur Richard constitution of 1946.

However, there is a wastage as earlier mentioned in the form of not meeting its desired or anticipated result at a scale considerably lower than it has set for itself, repetition and failure at the end of a course. If this is the case, why is it that many pupils in the primary school system do not want to go to school? Why do they encourage wastage of resources on the part of the government and their parents? What are the factors responsible for this act?

Dropout in its narrowest sense is referred to enrolled pupils who stay away from school for more than a given number of days without migrating with their parents. An intermediate concept of dropout means once enrolled pupils but leave education before completing a given circle while the third is a broader definition which embraces those who do not even enroll (e.g., some street children, handicapped children, children in remote rural areas) and cover the entire school career until legal school leaving age.

According to the report of Advanced level workshop on universalization of Education at primary level November (1984). Says: Any Child who enters into primary school but does not complete the 6 years cycle whatever the reason will be considered as dropout. Umoh (1986) view dropout as a pupil who because of unseen circumstance cannot complete a school program which she/he originally was enrolled for.

\section{PARENTS' SOCIO-ECONOMIC STATUS AND PUPILS DROPOUT IN SCHOOLS}

Socio economic status of parents contributes immensely to school dropout. Pupils that come from well to do and educated families try to persevere in school programme overcoming all the odds on the way to success, while those from poor and uneducated families do easily succumb to and thus dropout of the school system Osagie 2010. Okedara (1979) identified dropout as financial crisis. They revealed that dropouts are those pupils who could not pay their school fees and or who could not meet financial expenses.

Pupils from low income families are 2.4 times more likely to dropout of school than are children from middle income families and 10.5 times more likely than pupils from high-income families. All these factors are due to direct cost of education on parents. This direct cost includes school fees, cost of uniform, schoolbooks, school equipment, transportation system and a meal. The ability of each parent to be able to meet the needs of their children will determine their stability in the school. For pupils in rural areas, transportation cost can easily become the most expensive element of private cost of education. No school bus is provided; pupils either walk or use public transportation, ride bicycle or motor cycle. Parents admit that this extra expense is something they cannot afford to come up with on a daily basis and they would have little to argue if the children use this as an excuse to stay at home.

\section{EARLY MARRIAGE AND PUPILS ATTITUDE TO SCHOOL}

Early marriage is another problem that may automatically means the end of the school career. According to Egbule and Ugoji revealed that early marriage is another problem of adolescent among other demands made on them, early marriage and that of teenage pregnancy standout prominent. These two issues can create a lot of disturbances to the individuals. These may result in financial insecurity, poor job prospect and drastic change of attitude towards peer. It may also create the problems of the adolescent still depending on the parents even after getting children or married. They may find it impossible to continue with their education.

\section{GENDER AND PUPILS DROPOUT IN SCHOOLS}

Gender of pupils has effect on school dropout. Apparently, there is no remarkable difference in pupils' dropout between girls and boys. Both leave school for 
specific reasons: girls (pregnancy and marriage) boys (employment, behavioural difficulties). But boys are more prone to withdrawal from school system than girls. Furthermore, boys dropout of school because they want to acquire a skill early in order to earn their living. Some boys dropout of school to pursue business that is lucrative in nature. Okoye proclaims, No wonder that in Nnewi Local Government Area where business or trading is looked upon as the only source of making huge turnover boys looked down on any other profession. These ideas of pursuing money through business line by boys do automatically lure some of them to dropout from school while their counterparts (girl) are receiving their education.

Moreover, Kotwal et al. (2007) revealed that the main factors of dropout among girls from schools in rural areas were reluctance of parents and participation in domestic activities. The parents' educational statuses were poor and they did not give as much importance to the education of girls as they did to their sons. They believed their sons support them in their old age.

\section{PARENTS PERCEPTION OF THE VALUE OF EDUCATION AND PUPLS DROPOUT}

Another factor is parents' perception of the value of education. Parents can be unaware of the benefits of education even if the quality of education and the link between education and work are as they should be. In the rural areas, where the major source of income is agriculture, parents may have difficulties imagining lives for their children that are different from their own and thus tend to undervalue the potential benefits of education. Parents have control over their children therefore; parents' perception is an important factor in determining whether or not their children will attend school. According to the research conducted by faculty of Economics Thammasat University in 2000. It shows that mother's level of education is a significant factor in determining whether or not the children will go to school. Another study has shown that educated women help their children with homework and also support their children's ambition more. Collen (1969) Collected data concerning the educational experience of each child's parents' to test the hypothesis that the degree of parental education can be an important indicator of the educability of children. The educational attainment of parents were tabulated and a significant different was found between the educational rating of the performance of the children in the sample. Children from homes with educated parents performed better than those from homes with low or no education at all. Other reasons for the lack of parental supports and encouragement to go to school may be the parents' own illiteracy or inability to help them with their homework, their lack of information about return to education and their desire to have their children help them in the field while education is alienating them from trade or agricultural work.

\section{STATEMENT OF THE PROBLEM}

The crucial aspect of wastage in education system is dropout of pupils and this has caused problems to the individual's life, parents, government and the society. Such problems include the indiscipline and hooliganism, economic setback, stressful life situations, government wastage of school resources and capacity, set back to technological advancement, mass illiteracy, hooliganism/ gangsterism and moral decadence. Taking a through look at dropout of school pupils in this district, it can be hinged on the following points:

Socio-economic status of parents too low to meet up with their children's school demands e.g., cost of uniform, school books, writing materials, transportation etc. Instability of the school system as a result of regular strike and changes in government policies has prompted a lot of school pupils: girls into teenage pregnancy and early marriage, the boys into search of quick money, joining of gangs that are deviant in nature. The school curriculum is not qualitative in scope to meet the needs of pupils because of its theoretical nature. The teachers are not committed enough to their work and pupils due to irregular payment of salary. Lastly, most girls stay away from school regularly to help their parents in search of money and to care for their siblings. With the knowledge of the existence of these factors, it is needful to carryout a research on whether these perceived factors mentioned above are actually responsible for school dropout among primary school pupils, significantly or not. Therefore, the problem put in a question is: what are the perceived factors responsible for dropout in primary school in Delta Central Senatorial District of Delta State.

\section{HYPOTHESES}

The following null hypotheses were formulated to guide the study based on the problem:

- There is no significant difference among the perceptions of school heads, teachers and parents on parents' socio economic status as a factor responsible for dropout in primary schools

- There is no significant difference among the perceptions of school heads, teachers and parents on early marriage as a factor responsible for dropout in primary schools

- There is no significant difference among the perceptions of school heads, teachers and parents on gender as a factor responsible for dropout in primary schools 
- There is no significant difference among the perceptions of school heads, teachers and parents on the parents' perception of the value of education as a factor responsible for dropout in primary schools

\section{PURPOSE OF THE STUDY}

The purpose of this study therefore is to examine the perceived factors responsible for dropout in primary schools. The study therefore seeks to analyze the following:

- The perception of school heads, teachers and parents on parents'-socio economic status as a factor responsible for dropout in primary school

- The perception of school heads, teachers and parents on early marriage as a factor responsible for dropout in primary schools

- The perception of school heads, teachers and parents on gender as a factor responsible for dropout in primary schools

- The perception of school heads, teachers and parents on parents' perception of the value of education as a factor responsible for dropout in primary schools

\section{METHOD OF STUDY}

The survey design was employed in carrying out this study. This was to identify and make selection of variables which is considered relevant to this investigation. The population was drawn from Delta Central Senatorial District of Nigeria. The target population was all the primary schools in the district amounting to 36,600 pupils. This was a survey design involving 500 respondents.

The respondents are head of schools, teachers and parents. The simple random sampling technique was used in drawing the sample size. This was done to ensure that, every member of the population have equal chance of being selected as a member of the sample. Sample size of 50 head teachers 150 teachers and 300 parents were drawn respectively given a total of 500 respondents.

The main instrument which was used to gather information for the study was questionnaire. The questionnaire was divided into two sections. Section A sought to elicit information on the personal data of the respondents while section $\mathrm{B}$ sought to elicit information on dropout of pupils on a four-point Likert scale of Strongly Agree (SA) which attracts four (4) points, Agree (A) three (3) points, Disagree (D) two (2) points and strongly Disagree (SD) one (1) point. It was a thirty item questionnaire which sought to elicit information on perceived factors responsible for dropout in primary school in Delta Central Senatorial District, Nigeria.

The split-half method was used to determine the reliability of the instrument. The spearman correlation coefficient was used in analyzing it which gave a value of reliability coefficient of 0.87 . The Analysis Of Variance (ANOVA) was employed to test for significant difference at 0.05 level for retaining or rejecting each of the null hypotheses formulated in the study.

\section{RESULTS}

Hypothesis I: There is no significant difference among the perception of school heads, teachers and parents on parents socio economic status as a factor responsible for dropout in primary schools.

The result showed in the Table 1 that there was no significant difference among the perception of school heads, teachers and parents on parents socio economic status as a factor responsible for dropouts in primary school. The F-calculated value of 0.004 was less than Fcritical of 2.62 ; result was not significant at 0.05 levels, therefore: the null hypothesis was retained.

Hypothesis 2: There is no significant difference among the perception of school heads, teachers and parents on early marriage as a factor responsible for dropout in primary schools.

The result showed in Table 2 that there was no significant difference among the perception of school heads, teachers and parents on early marriage as a factor responsible for dropout in primary schools. The Fcalculated value of 0.003 was less than $F$-critical values of 2.62. The result was not significant at 0.05 levels. Therefore the null hypothesis was retained.

Hypothesis 3: There is no significant difference among the perception of school heads, teachers and parents on gender as a factor responsible for dropout in primary schools.

The result showed in Table 3 there was no significant difference among the perception of the school heads, teachers and parents on gender as a factor responsible for dropout in primary school.

This was because the F-calculated which is 0.007 was less than F-critical value of 2.62 , result was not significant at 0.05 levels of significance. The null hypothesis was therefore retained. 
Pak.J.Soc. Sci., 7 (5): 365-370, 2010

Table 1: Analysis of variance of the degrees of freedom sums of square and mean square of the perception of school heads, teachers and parents on socioeconomic status as a factor responsible for dropout in primary schools

\begin{tabular}{lrrrrrr}
\hline Sources of variation & DF & SS & MS & F-cal & F-crit & Decision point \\
Between group & 2 & 45 & 22.5 & - & - & Nemarks \\
With in group & 452 & 2931521 & 6485.5 & 0.004 & 2.62 & - \\
Total & 454 & 2931566 & - & - & - & - \\
\hline
\end{tabular}

Table 2: Analysis of variance of the degrees of freedom sums of square and mean square of the perception of school heads, teachers and parents on early marriage as a factor responsible for dropout in primary schools

\begin{tabular}{lrrrrrr}
\hline Sources of variation & DF & SS & MS & F-cal & F-crit & Recision point \\
Between group & 2 & 36 & 18 & - & - & Not significant \\
With in group & 452 & 3075153 & 6803.3 & 0.003 & 2.62 & - \\
Total & 454 & 3075189 & - & - & - & - \\
\hline
\end{tabular}

Table 3: Analysis of variance of the degrees of freedom, sums of square and mean square of the perception of school heads, teachers and parents on gender as a factor responsible for dropout in primary schools

\begin{tabular}{lrrrrrr}
\hline Sources of variation & DF & SS & MS & F-cal & F-crit & Decision point \\
Between group & 2 & 82 & 41 & - & - & - \\
With in group & 452 & 2841418 & 6286.1 & 0.007 & 2.62 & Not significant \\
Total & 454 & 2841500 & - & - & - & - \\
\hline
\end{tabular}

Table 4: Analysis of variance of the degrees of freedom sums of square and mean square of the perception of school heads, teachers and parents on parents' perception of the value of education as a factor responsible for dropout in primary schools

\begin{tabular}{lrrrrrr}
\hline Sources of variation & DF & SS & MS & F-cal & F-crit & Decision point \\
Between group & 2 & 20 & 10 & - & - & Remarks \\
With in group & 452 & 2883915 & 6380 & 0.002 & 2.62 & - \\
Total & 454 & 2883935 & - & - & - & - \\
\hline
\end{tabular}

Hypothesis 4: There is no significant difference among perception of school heads, teachers and parents on parents perception of the value of education as a factor responsible for dropout in primary schools. The result showed in Table 4 there was no difference among the perception of school heads, teachers and parents on parents perception of the value of education as a factor responsible for dropout in primary schools. This was so because the $\mathrm{F}$-calculated value of 0.002 was less than the F-critical value of 2.62. The result was not significant at 0.05 levels of significance. Therefore, the null hypothesis was retained.

\section{DISCUSSION}

The first hypothesis revealed there was no significant difference among the perception of school heads, teachers and parents on parents socio economic status as a factor responsible for dropout in primary school. Osagie, revealed that those pupils who could not pay their school fees and or who could not meet financial expenses drop out from the schools. The second finding revealed there was no significant difference among the perception of the school heads, teacher and parents on early marriage as a factor responsible for dropout in primary schools. Despite the fact that the National Policy on Education (FRN, 2004) incorporated the provision of day care services, pre-nursery and nursery schools into educational system to help the nursing mothers to take care of their babies so as to be able to handle other issues of life such as education yet it is not been patronized either due to lack of awareness or not affordable, hence the high level of dropout using early marriage as a measure in Delta Central Senatorial District. The third finding shows that there was no significant difference among the perception of school heads, teachers and parents on gender as a factor responsible for dropout in primary schools. There are fewer dropouts among girls than boys. Nakpodia (2010) revealed that the main factor for dropout of girls from school in rural areas were reluctance of parents and participation in domestic activities. Parents in rural areas do not give much importance to the education of girls as they did to their sons. They perceived that sons support them in their old age. The fourth finding showed there was no significant difference among the perception of school heads, teachers and parents on parent perception on the value of education as a factor responsible for dropouts in primary school.

This is in line with Collen (1969) who collected data concerning the educational experience of each child's parents to test the hypothesis that the degree of parental education can be an important indicator of the educability of children. The educational attainment of parent's was tabulated and a significant difference was found between the educational ratings of the performance of the children in the sample. Children from homes with high educated parents performed better than those from homes with low or no education at all.

\section{CONCLUSION}

On the basis of the findings, the following conclusions emerged. Parents socio-economic status was 
identified as a factor that affects dropout in primary schools. Early marriage was identified as a factor, that affects dropout in primary schools. Gender was identified as a factor that affects dropout in primary schools. Perception of the value of education was identified as a factor that affects dropout in primary schools.

\section{RECOMMENDATIONS}

On the basis of the findings and conclusions from the study, the following recommendations were made:

- There are costs which are unavoidable in order to participate fully in education. Examples include textbooks, writing materials and exercise books. These should be given freely to the pupils in their various schools

- There is a need for sensitization of the pupils on the implications of early dating and marriage through parent discipline, inculcation of moral values and decency that pupils need to change. Schools, communities must learn to provide support rather than exclude the pupils involved

- There should be no gender differences; parents should bridge the gap of differential treatment among their children. The two sexes should be given equal growth and development of potential ability that can cause them to become self-reliant in life, useful to themselves, the community and the society at large

- In case of parents' perception to the value of education, the key concepts here include awareness, campaigns, parental education and parental participation in the structure and management of the schools

- Teachers should be provided with teaching materials such as teacher's guide, textbooks and instructional materials that are related to teaching
- Lastly and most importantly, Maria Montessori type of education where there are enough equipment, Aesthetic play ground and environment, enough educational toys, modelling materials, committed teachers with skills acquisitions are needed in the primary schools

\section{REFERENCES}

Collen, K., 1969. School and Family. Gill and Macmillan Press, Dublin.

FRN. (Federal Republic of Nigeria), 2004. National Policy on Education-Nigeria. NERDC Press, Yaba, Lagos, Nigeria.

Fafunwa, A.B., 1983. Drop-ins and Drop-outs in the Nigeria Education System. University of life Dress Ltd. Ile-Ife, Nigeria.

Kotwal, N., Neelima and S. Rani, 2007. Causes of school dropouts among rural girls in Kathua District. J. Hum. Ecol., 22: 57-59.

Nakpodia, E.D., 2010. An analysis of dropout rate among secondary school students in Delta State, Nigeria (1990-2005). J. Soc. Sci., 23: 99-103.

Okedara, J.T., 1979. A preliminary study of primary school with drawals in Western states of Nigeria 1955-1974. Nigeria Institute of Social and Economic Research, Ibadan.

Schwartz, W., 1995. School dropout, new information about an old problem. National Center for Education Statistics.

Umoh, S.H., 1986. Comparative study of perception of school dropout by principal and students in selected school in Kwara state. The Nig. J. Guidance Counselling, 2: 15-25. 